\title{
Grandparents Raising Grandchildren: Characteristics of Strong Families ${ }^{1}$
}

Millie Ferrer-Chancy, Larry F. Forthun, Angela Falcone, and Joe Pergola ${ }^{2}$

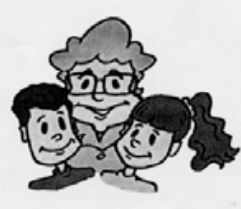

Goal: To describe characteristics of strong families to grandparents who are raising grandchildren to help them establish a healthy family

\section{Defined Set of Beliefs and Values}

Your decision to take care of your grandchildren shows you value family unity. Beliefs and values make you who you are. They are what you hold dear and what you believe is right for your family. They are created by the experiences you've had in life and help guide you through life.

Different families value different things. For example, one family may value having dinner together. If the child misses dinner, the family is likely to

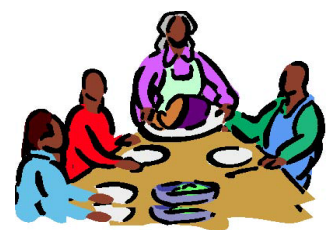
be upset because the child didn't respect the family's value. But another family may not think this time together is important and is likely not to be upset if the child misses dinner. This family may have an unspoken rule that family members can eat dinner whenever and wherever they want.

Another value you may hold dear is commitment. Families who invest time and energy into creating and sustaining healthy relationships show commitment. They support each other and believe that family comes first. They also know they can depend on and trust each other. There are other beliefs and values that are common in strong families including:
- loyalty

- honesty

- time together

- family traditions

- respect for others

- a positive outlook

- $\quad$ spirituality/religion

- following through on promises

- $\quad$ sticking together during rough times

If you could add to this list of values, what would you add? Write them down and think about ways you can teach these values to your grandchildren. Don't expect your grandchildren to automatically know what you value and believe; they must be taught in a loving and caring way. Simply punishing a grandchild for violating a rule that reflects your values (like not being home for dinner) does not teach them your values. Talk with your grandchildren and let them know that you value them and want them to be a part of your family.

\section{Healthy Limits}

Rules are a reflection of your values and beliefs and play an important role in building and maintaining strong families. As a grandparent, you are the authority figure. Part of your role is to set clear, appropriate limits for

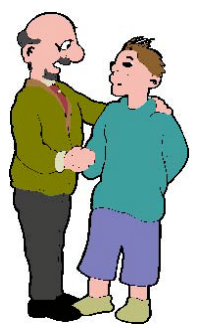
your grandchildren.

Rules that are explicit and clear can help you deal with such issues as discipline. Without clear-cut rules, your grandchildren may overstep the limits you want to establish. With clear rules, each grandchild knows what is expected, and therefore feels secure. When your grandchildren feel secure they are able

1. This document, adapted from the 2002 version of FCS2190, is FCS2190a, one of a series of the Department of Family, Youth and Community Sciences, Florida Cooperative Extension Service, Institute of Food and Agricultural Sciences (IFAS), University of Florida. Publication date: August 2009. Please visit the EDIS Web site at http://edis.ifas.ufl.edu.

2. Millie Ferrer-Chancy, Ph.D., interim dean, Florida Cooperative Extension Service, University of Florida; Larry F. Forthun, Ph.D., assistant professor, Department of Family, Youth and Community Sciences; Angela Falcone and Joe Pergola, former FYCS graduate students; Institute of Food and Agricultural Sciences, University of Florida, Gainesville, FL 32611. 
to explore and take risks necessary to grow

physically, mentally, socially, and emotionally.

Healthy rules need to be established when sharing feelings, setting expectations, and giving choices to your grandchildren.

\section{Sharing feelings}

Why should there be a "rule" about sharing feelings? First of all, children need to learn how to handle feelings. You will be your grandchildren's role model for how they handle different life situations.

However, it is inappropriate to treat them as your best friend by telling them adult details. For example, you might be angry with your spouse or the child's parent. If your grandchild asks you what is wrong, you could share that you had a disagreement. Do not give intimate details of your argument. Having such a rule (or boundary) helps to protect your grandchildren from believing THEY are "responsible" for your feelings.

\section{Setting expectations}

Creating rules that are age-appropriate is important in establishing good boundaries. To set appropriate rules, you must understand each grandchild's stage of development (see in this series: A Crash Course in Child Development). If you set a rule that is beyond their level of understanding, you will set them up for failure. For example, you might expect your grandchild, age 2, to sit quietly without causing disruptions while waiting at the local health center. It's not practical to expect a toddler to sit quietly for any length of time. They are curious by nature and have short attention spans. If you need to take your grandchild with you, bring along toys, activities, and snacks to make the time less frustrating.

\section{Giving choices}

Part of healthy development is being able to make your own decisions and as the adult in charge, you need to know when to let your grandchildren make their own decisions. You also need to know when to set limits for their decisions.

We can start teaching children to make decisions early. For example, an age-appropriate choice would be asking your 6-year-old grandchild if he would like to have spaghetti or a sandwich for lunch. Another age-appropriate decision is letting your 13-year-old choose which school activities to be involved in. However, some decisions need to be made by you. These decisions may include acceptable bedtime, television programs, Internet and video games, or curfew.

\section{Ability to Adapt to Change}

Change is bound to happen and families need to be flexible and learn to adapt to new situations. The ability to adapt to change has to do with your attitude and how willing you are to accept change. For example, the parenting strategies you use with your preschooler need to be different from the ones you will use when your grandchild becomes a teenager. You will create unnecessary conflict if you continue to use the same parenting strategies and are unwilling to change.

\section{Good Communication}

Communication involves the exchange of words, ideas, and feelings between two people. It is what we say (verbal) and how we say it (nonverbal). Healthy families strive for good communication. Yet, good communication can be difficult when each family member has a different idea of how to communicate well. For example, grandparents who constantly talk "at" their grandchildren by giving commands (e.g., "Clean your room") and lecturing (e.g., "Don't talk with your mouth full") may believe this is good communication. However, it is best for grandparents to talk "with" their grandchildren. Talking with grandchildren means not only speaking to them but also listening to what they have to say.

There are specific skills that families can learn to improve their communication. These include:

- Talking with and listening to each other

- $\quad$ Speaking directly without blaming

- Having empathy for one another

- $\quad$ Sharing feelings

- Using humor

- $\quad$ Solving problems as a family

Many changes will occur in your life as you take on your new parenting role. What distinguishes healthy families from unhealthy families is that they have these characteristics. In the next publication, Building Strong Families, you will learn more about how to develop the skills to become a strong family.

\section{References}

Olson, D.H., DeFrain, J., \& Skogrand, L. (2008). Marriages and Families: Intimacy, diversity, and strengths. Boston, MA: McGraw-Hill.

Schenck, B.R. (1997). Winning ways to talk with young children. University of Florida, Cooperative Extension. 10pp. FCS 2021.

Walsh, F. (2006). Strengthening family resilience. New York: Guilford Publication Inc. 